\begin{tabular}{rl|l} 
Cellular Physiology & Cell Physiol Biochem 2012;30:259-268 & \\
\cline { 2 - 3 } DOI: 10.1159/000339062 & $\begin{array}{l}\text { O 2012 S. Karger AG, Basel } \\
\text { www.karger.com/cpb }\end{array}$ \\
\hline and Biochemistry & Published online: June 19, 2012 & $1015-8987 / 12 / 0301-0259 \$ 38.00 / 0$
\end{tabular}

\title{
SGK1 Sensitivity of Platelet Migration
}

\author{
Eva-Maria Schmidt ${ }^{1, *}$ Bjoern F. Kraemer ${ }^{2, *}$ Oliver Borst ${ }^{1,2}$ Patrick Münzer ${ }^{1}$ Tanja \\ Schönberger ${ }^{2}$ Christine Schmidt ${ }^{2}$ Christina Leibrock ${ }^{1}$ Syeda T. Towhid ${ }^{1}$ Peter \\ Seizer $^{2}$ Dietmar Kuhl ${ }^{3}$ Christos Stournaras ${ }^{4}$ Stephan Lindemann ${ }^{2}$ Meinrad \\ Gawaz $^{2}$ Florian Lang ${ }^{1}$
}

\begin{abstract}
${ }^{1}$ Department of Physiology, University of Tübingen, ${ }^{2}$ Department of Cardiology and Cardiovascular Medicine, University of Tübingen, ${ }^{3}$ Center for Molecular Neurobiology (ZMNH), Institute for Molecular and Cellular Cognition (IMCC), University Medical Center Hamburg-Eppendorf (UKE), ${ }^{4}$ Department of Biochemistry, University of Crete Medical School, Heraklion , ${ }^{\star}$ contributed equally and thus share first authorship
\end{abstract}

\section{Key Words}

Platelets • Migration • SDF-1 - WASP • Vinculin • SGK1

\begin{abstract}
Recent observations pointed to the ability of platelets to migrate and thus to invade the inflamed vascular wall. Platelet migration could be stimulated by stromal cell-derived factor-1 (SDF-1), an effect dependent on phosphatidylinositide-3-kinase (PI3K) and paralleled by activation and phosphorylation of Wiskott-Aldrich syndrome protein (WASP). Migration is inhibited by vinculin, which is similarly regulated by phosphorylation. PI3K-sensitive kinases include the serum- and glucocorticoid-inducible kinase 1 (SGK1). The present study explored whether SGK1 modifies WASP and vinculin phosphorylation in murine platelets and participates in the regulation of platelet migration. Platelets were isolated from gene-targeted mice lacking SGK1 $\left(s g k 1^{--}\right)$and from their wild type littermates $\left(s g k 1^{+/+}\right)$. Platelet migration stimulated with SDF-1 was significantly less pronounced in $s g k 1^{-/}$platelets than in $s g k 1^{+/+}$platelets. Moreover, SDF-1 significantly induced WASP phosphorylation, an effect again reduced in platelets lacking SGK1. Phosphorylation of vinculin was significantly enhanced in $s g k 1^{-/}$platelets and was significantly reduced following treatment of platelets with $\mathrm{Ca}^{2+}$ chelator BAPTA. Immunohistochemical analysis of in vivo experiments in intestinal vessels after vascular inflammation revealed that transmigration of platelets into inflamed vessel walls was significantly less pronounced in $s g k 1^{-/}$than in $s g k 1^{+/+}$mice. In conclusion, SGK1 is a powerful regulator of platelet migration.
\end{abstract}

Copyright (c) 2012 S. Karger AG, Basel

\section{Introduction}

Upon activation platelets adhere to the vascular wall and expose binding sites to other platelets and circulating cells in the blood stream [1]. The adherence may be followed by 


\begin{tabular}{|c|c|c|}
\hline $\mathrm{Col}$ & Cell Physiol Biochem 2012;30:259-268 & \\
\hline and Binchemistry & $\begin{array}{l}\text { DOI: 10.1159/000339062 } \\
\text { Published online: June 19, } 2012\end{array}$ & $\begin{array}{l}\text { (c) } 2012 \text { S. Karger AG, Basel } \\
\text { www.karger.com/cpb }\end{array}$ \\
\hline
\end{tabular}

migration into the vascular wall [2-5]. Platelet migration is paralleled by activation and phosphorylation of Wiskott-Aldrich syndrome protein (WASP) [3, 6], in other cell types an essential component of the migratory machinery [7-9]. As shown in other cell types [1012], migration is suppressed by the ubiquitously expressed actin-binding protein vinculin, which impedes cellular motility by stabilizing focal adhesions. Activation of vinculin by phosphorylation results in an inhibiton of cell motility $[12,13]$.

Platelet migration can be stimulated by stromal cell derived factor-1 (SDF-1) [3], a potent inflammatory chemokine highly expressed in atherosclerotic plaques [14]. SDF-1 is stored in platelet granules and induces chemotactic migration of several cell types [15-18]. SDF-1 binds to and activates the CXCR4 receptor $[19,20]$. SDF-1-induced platelet migration requires the CXCR4 receptor, phosphatidylinositide-3-kinase (PI3K) signaling and rearrangement of the actin cytoskeleton [3]. Downstream signaling linking PI3K to migration of platelets remained elusive. Kinases activated by PI3K include the serum- and glucocorticoid-inducible kinase 1 (SGK1) [21-23], which is an important regulator of platelet function [24]. So far the functional role of SGK1 in the regulation of platelet mobility has not been investigated.

The present study thus explored the putative role of SGK1 in the regulation of platelet migration induced by SDF-1 and potential implications for platelet migration in vascular inflammation.

\section{Materials and Methods}

Mice

Gene-targeted mice lacking functional SGK1 $\left(\mathrm{sgk1} 1^{-}\right)$and the corresponding wild type littermate mice $\left(s g 1^{+/+}\right)$were generated and bred as described earlier [25]. Animals were genotyped by polymerase chain reaction (PCR). All animal experiments were conducted according to German law for the welfare of animals and were approved by local authorities.

\section{Preparation of murine platelets}

Platelets were obtained from 10 - to 12 -week-old $s g k 1^{1-}$ and $s g k 1^{+/+}$mice of either sex as described previously [24]. The mice were anesthetized with ether and blood was drawn from the retroorbital plexus into heparinized tubes. Blood parameters were analyzed with pocH-100iv automatic hematology analyzer (Sysmex). Platelet rich plasma (PRP) was obtained by centrifugation at $260 \mathrm{~g}$ for 5 minutes. Afterwards PRP was centrifuged at $640 \mathrm{~g}$ for 5 minutes to pellet the platelets. To ease platelets apyrase $(0.02 \mathrm{U} / \mathrm{ml}$, SigmaAldrich) and prostaglandin $\mathrm{I}_{2}(0.5 \mu \mathrm{M}$, Calbiochem) were added to the PRP. After two washing steps the pellet of washed platelets was resuspended in modified Tyrode-HEPES buffer ( $\mathrm{pH}$ 7.4, supplemented with $1 \mathrm{mM} \mathrm{CaCl}_{2}$ ).

\section{Transwell experiments}

For transmigration experiments, we used transwell inserts (24-well, Falcon) separating the upper and the lower chamber with a membrane with pores that were $0.4 \mu \mathrm{m}$ in diameter. The lower chamber contained SDF-1 (100 ng/ml, R\&D Systems) or solvent control in IMDM medium. Murine platelets $\left(5 \times 10^{6}\right.$ platelets/ $\mathrm{ml}$ ) were carefully transferred into the upper chamber and were allowed to migrate through the membrane for 8 hours in IMDM medium under cell culture conditions in a stable humidified atmosphere $\left(5 \% \mathrm{CO}_{2}\right.$, $\mathrm{pH} 7.4,37^{\circ} \mathrm{C}$ ). Afterwards the platelet suspension in the lower compartment was stained with an antibody against the platelet-specific glycoprotein Ib $\alpha$ (GPIb $\alpha$, platelet-specific; Beckman Coulter, Immunotech). Then platelets of the lower compartment were counted by flow cytometry (BD FACS Calibur) in the platelet gate. Flow cytometric readout was confirmed by visual counting of platelets with a hemocytometer.

Images of migrated platelets at the bottom of the removed chamber membranes stained with rhodamine-phalloidin (red) and the platelet-specific glycoprotein Ib $\alpha$ (blue) were taken on a Zeiss LSM 5 EXCITER confocal laser scanning microscope (Carl Zeiss Micro Imaging GmbH, Germany) with an A-plan $40 \times / 0.65$ PH2 ocular. 


\section{Cellular Physiology Cell Physiol Biochem 2012;30:259-268

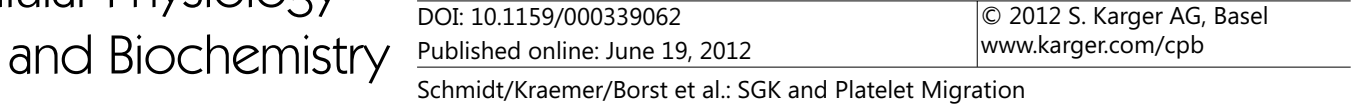

was added and the protein concentration was measured with Bradford (Biorad). $30 \mu \mathrm{g}$ of protein was taken for each sample. Roti ${ }^{\circledR}$-Load1 (Roth) was added and the samples boiled for 10 minutes at $95{ }^{\circ} \mathrm{C}$. For immunoblotting proteins were electrotransferred onto a nitrocellulose membrane and blocked with $5 \%$ bovine serum albumin in TBS-0.1\% Tween 20 (TBST) at room temperature for 1 hour. Then, the membrane was incubated with the primary antibody against $\beta$-actin (1:1000, Cell Signaling), phosphorylated WASP $(1: 250$, Abcam $)$ or phosphorylated vinculin $(1: 250, \mathrm{Abcam})$ at $4{ }^{\circ} \mathrm{C}$ overnight. After washing with TBST the blots were incubated with secondary antibody conjugated with horse radish peroxidase (HRP) (1:2000, Cell Signaling) for 1 hour at room temperature. After washing antibody binding was detected with the ECL detection reagent (Amersham). Bands were quantified with Quantity One Software (Biorad).

Immunofluorescence and confocal microscopy

Washed platelets were allowed to adhere to a fibrinogen surface $(20 \mu \mathrm{g} / \mathrm{ml})$ on a chamber slide. Cells were fixed with paraformaldehyde (2\%), washed and blocked with $2 \%$ bovine serum albumin for 30 minutes, followed by incubation with the primary antibody for 2 hours at room temperature. Primary antibodies against phospho-WASP (1:250, Abcam) or phospho-vinculin (1:250, Abcam) were used. Chamber slides were washed and incubated with an anti-rabbit FITC-conjugated secondary antibody (Santa Cruz). The actin cytoskeleton was stained with rhodamine-phalloidin (Invitrogen). The slides were mounted with ProLong Gold antifade reagent (Invitrogen). Confocal microscopy was performed using a Zeiss LSM5 EXCITER Confocal Laser Scanning Microscope (Carl Zeiss Micro Imaging) with a A-Plan 63x ocular.

Platelet transmigration into areas of vascular inflammation in vivo after intestinal artery ligation and reperfusion

For analysis of transmigration into inflamed tissue $s g k 1$-deficient mice or wild type littermates were anesthetized by intraperitoneal injection of midazolame ( $5 \mathrm{mg} / \mathrm{kg}$ body weight; Ratiopharm), medetomidine $(0.5 \mathrm{mg} / \mathrm{kg}$ body weight; Albrecht) and fentanyl $(0.05 \mathrm{mg} / \mathrm{kg}$ body weight; CuraMed Pharma $\mathrm{GmbH})$ and placed on a heating pad for maintenance of body temperature between $36^{\circ} \mathrm{C}$ and $37{ }^{\circ} \mathrm{C}$. After transverse laparotomy, a segment of the jejunum was gently exteriorized. Segmental intestinal ischemia was induced by ligation of the supplying vessels and the segment itself for 1 hour. Subsequently, the abdomen was closed in layers and the anesthesia was antagonized by a subcutaneous injection of flumazenil $(0.5 \mathrm{mg} / \mathrm{kg}$ body weight; Fresenius Kabi) and atipamezole ( $2.5 \mathrm{mg} / \mathrm{kg}$ body weight; Albrecht). After 3 hours of reperfusion the mice were killed and samples of injured and intact intestine were removed, embedded in Tissue-Tek $₫$ O.C.T. ${ }^{\mathrm{TM}}$ and cut into $5 \mu \mathrm{m}$ cryosections.

The sections were fixed with acetone and blocked with Protein Block Serum-free (Dako), followed by incubation with rat anti-mouse GPIb $\alpha$ monoclonal antibody (1:100, emfret analytics) for 1 hour at room temperature. After washing and incubation with a biotinylated rabbit anti-rat secondary antibody (Dako) the sections were stained with an avidin-biotin-immuno-peroxidase method (Liquid DAB+ Substrate Chromogen System, Dako).

Statistical analysis

Data are given as mean \pm SEM. A p-value less than 0.05 was considered significant by unpaired student's $t$-test.

\section{Results}

\section{SGK1 regulates platelet migration}

Migration of platelets requires activation of the phosphatidylinositide- 3 kinase (PI3K) pathway, which includes activation of the serum- and glucocorticoid-inducible kinase SGK1. Thus, experiments were performed in platelets isolated from gene-targeted mice lacking functional SGK1 $\left(s g k 1^{-/}\right)$and the corresponding wild type littermate mice $\left(s g k 1^{+/+}\right)$. Both, prior to and following stimulation with SDF-1, migration was significantly less pronounced in $s g k 1 \%$ platelets than in $s g k 1^{+/+}$platelets (Fig. 1, normalized values). The total number of transmigrated platelets was $4820 \pm 276 \mathrm{in} \mathrm{ggk} 1^{+/+}$and $3646 \pm 311 \mathrm{in} \mathrm{sgk} 1^{-/-}$before stimulation, and $10788 \pm 961$ in $s g k 1^{+/+}$and $5815 \pm 1077$ in $s g k 1^{-/}$after stimulation with SDF-1. 


\section{Cellular Physiology Cell Physiol Biochem 2012;30:259-268 \begin{tabular}{ll|l} 
and BiOChemistry & $\begin{array}{l}\text { DOI: 10.1159/000339062 } \\
\text { Published online: June 19, } 2012\end{array}$ & $\begin{array}{l}\text { C 2012 S. Karger AG, Basel } \\
\text { www.karger.com/cpb }\end{array}$ \\
\cline { 2 - 3 }
\end{tabular}
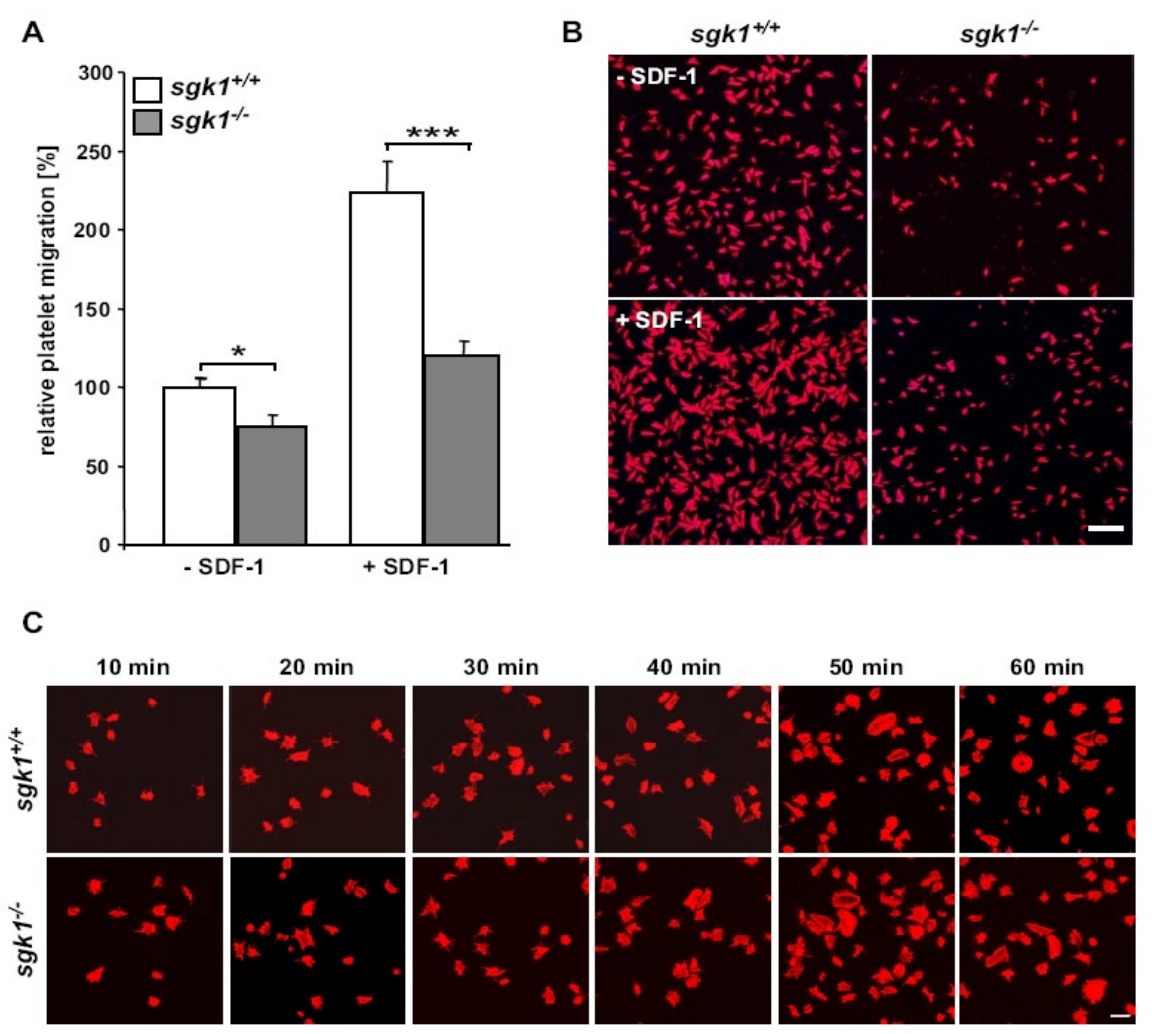

Fig. 1. SDF-1-induced migration of $s g k 1^{+/+}$and $s g k 1^{\%}$ platelets. A. Arithmetic means \pm SEM of transmigrated platelets (in percent of spontaneous $s g k 1^{+/+}$platelet migration in the absence of SDF-1, $\mathrm{n}=7$ ) isolated from $s g k 1^{1 /}$ mice (grey bars) or $s g k 1^{+/+}$mice (white bars) following exposure to SDF-1 $(100 \mathrm{ng} / \mathrm{ml}) .{ }^{* * *}(\mathrm{p}<0.01)$ and $*(\mathrm{p}<0.05)$ indicate statistically significant difference to respective value of $s g k 1^{+/+}$platelets. B. Representative immunofluorescence stainings of migrated platelets isolated from gene-targeted mice lacking SGK1 $\left(s g k 1^{-/}\right)$or their wild type littermates $\left(s g k 1^{+/}\right)$after transmigration through porous membranes of a transwell chamber towards SDF-1. Migrated murine platelets at the bottom of the removed transwell membranes were stained with rhodamine-phalloidin (red) and the platelet-specific glycoprotein Ib $\alpha$ (blue). Scale bar equals $10 \mu \mathrm{m}$. C. Adhesion kinetics of $s g k 1^{\%}$ and $s g k 1^{+/+}$platelets to a fibrinogen coated surface from 10 to $60 \mathrm{~min}$. Red - actin, scale bar represents $5 \mu \mathrm{m}$.

There was no obvious difference between $s g k 1^{1 /}$ and $s g k 1^{+/+}$mice in adhesion kinetics on a fibrinogen coated surface (Fig. 1C).

Activation of the migratory machinery is compromised in sgk1-deficient platelets.

Further experiments addressed phosphorylation of proteins known to be involved in the regulation of migration by interference with the actin cytoskeletal architecture. As illustrated in Fig. 2, SDF-1 exposure for 30 minutes was followed by a marked increase of Wiskott-Aldrich syndrome protein (WASP) phosphorylation in $s g \mathrm{k}^{+/+}$platelets, an effect significantly blunted in $s g k 1 \%$ platelets. Results were quantified by western blot analysis and confocal microscopy of expression of phosphorylated WASP.

As illustrated in Fig. 3, phosphorylation of vinculin was also sensitive to SGK1. Both, prior to and following stimulation with SDF-1 for 30 minutes, vinculin phosphorylation was significantly more pronounced in $\mathrm{sgk1 \%}$ platelets than in $\mathrm{sgk} 1^{+/+}$platelets. Phosphorylation of vinculin in platelets was not significantly affected by SDF-1. The increased vinculin phosphorylation in $s g k 1 \%$ platelets was reversed by pretreatment with $30 \mu \mathrm{M} \mathrm{Ca}^{2+}$ chelator BAPTA (Fig. 3E). 


\section{Cellular Physiology $\quad$ Cell Physiol Biochem 2012;30:259-268 \\ \begin{tabular}{ll|l} 
and BiOChemistry & $\begin{array}{l}\text { DOI: 10.1159/000339062 } \\
\text { Published online: June 19, } 2012\end{array}$ & $\begin{array}{l}\text { C 2012 S. Karger AG, Basel } \\
\text { www.karger.com/cpb }\end{array}$ \\
\cline { 2 - 3 } & Schmidt/Kraemer/Borst et al.: SGK and Platelet Migration
\end{tabular}}

A

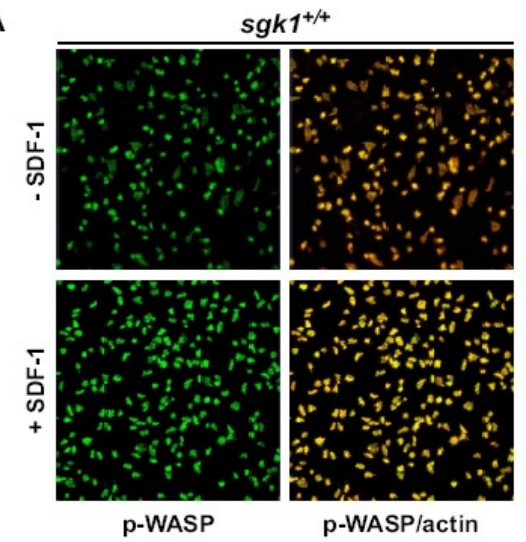

B

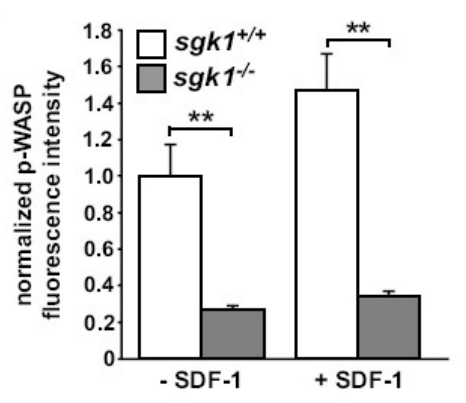

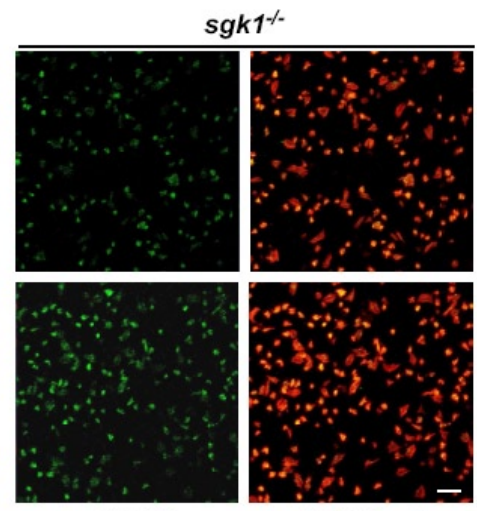

p-WASP/actin

C

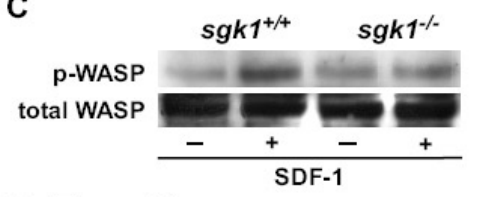

D

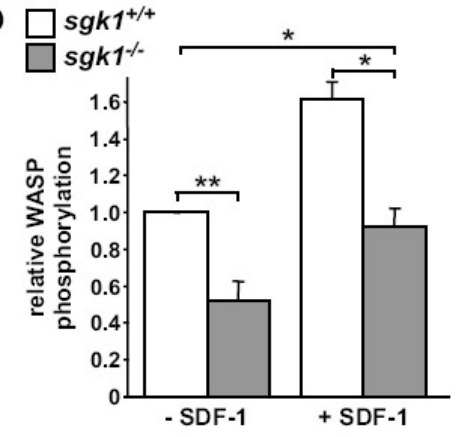

Fig. 2. Effect of SGK1 on WASP phosphorylation in SDF-1-stimulated murine platelets. A. Confocal microscopy of WASP phosphorylation in platelets from $s g k 1^{+/+}$(left panels) and $s g k 1^{-/-}$(right panels) mice without (top) or with (bottom) exposure to SDF-1 (100 ng/ml) for 30 minutes. Red - actin, green - phosphorylated WASP. Scale bar equals $5 \mu \mathrm{m}$. B. Arithmetic means \pm SEM $(\mathrm{n}=5)$ of the immunofluorescence intensity of WASP phosphorylation in platelets isolated from $s g k 1^{+/+}$(white bars) or $s g k 1^{\%-}$ mice (grey bars) without (left) or with (right) exposure to SDF-1 $(100 \mathrm{ng} / \mathrm{ml})$ normalized to $1 .{ }^{* *}(\mathrm{p}<0.01)$ indicates statistically significant difference to respective value of $s g k 1^{+/+}$platelets. C. Original western blot of the abundance of phosphorylated WASP in platelets isolated from $s g k 1^{+/+}$or $s g k 1^{1 /}$ mice without (control) or with prior exposure to SDF-1 (100 $\mathrm{ng} / \mathrm{ml}$ ) for 30 minutes. Total WASP protein abundance served as loading control. D. Arithmetic means \pm SEM ( $\mathrm{n}=3$ ) of the abundance of phosphorylated WASP from western blot in platelets from $\mathrm{sgk1^{+/+ }}$ (white bars) and $s g k 1^{-/}$(grey bars) mice without (left) or with (right) exposure to SDF-1 $(100 \mathrm{ng} / \mathrm{ml})$ for 30 minutes. * $(\mathrm{p}<0.05)$ or $* *(\mathrm{p}<0.01)$ indicate statistically significant difference.

Sgk1-deficient platelets show decreased transmigration into areas of post-ischemic vascular inflammation in vivo.

A final series of experiments explored the in vivo significance of SGK1-sensitive migration. To this end, the transmigratory potential of platelets into ischemic vessels was determined. Intestinal blood vessels of $s g k 1^{+/+}$and $s g k 1 \%$ mice were inflamed by ischemia and the immigrated platelets were stained with a platelet specific anti-GPIb $\alpha$ antibody and counted after fixation, cryosectioning and staining with GPIb $\alpha$. As illustrated in Fig. 4, the postischemic vascular walls of $s g k 1^{+/+}$mice showed significantly higher rates of transmigrated platelets than the inflamed vessels of $\mathrm{sgk} 1 \%$ mice. 


\section{Cellular Physiolosy Cell Physiol Biochem 2012;30:259-268 \\ \begin{tabular}{ll|l} 
and BiOChemistry & $\begin{array}{l}\text { DOI: 10.1159/000339062 } \\
\text { Published online: June 19, } 2012\end{array}$ & $\begin{array}{l}\text { C 2012 S. Karger AG, Basel } \\
\text { www.karger.com/cpb }\end{array}$ \\
\cline { 2 - 3 } & Schmidt/Kraemer/Borst et al.: SGK and Platelet Migration
\end{tabular}}

A

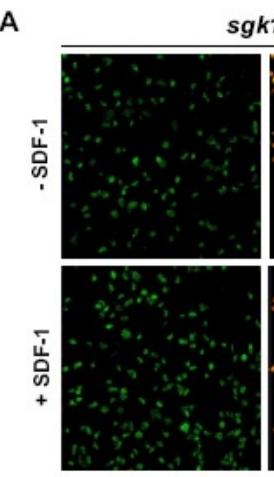

p-vinculin

B
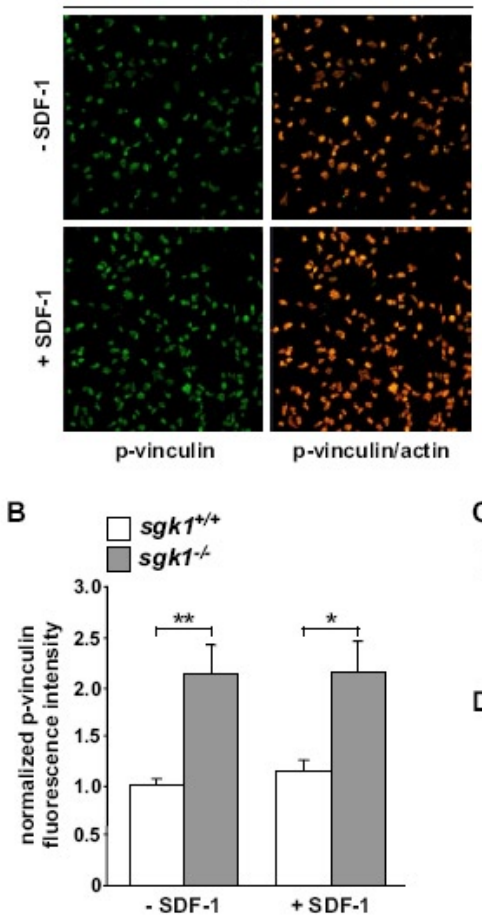

p-vinculin/actin

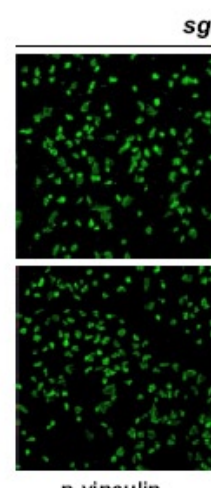

$\operatorname{sgk1/-}$

C

p-vinculin

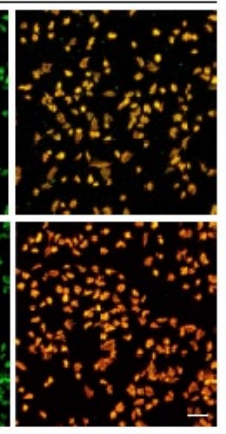

p-vinculin/actin

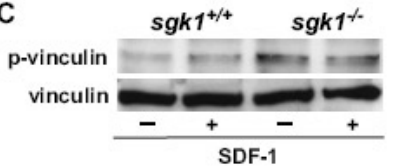

D

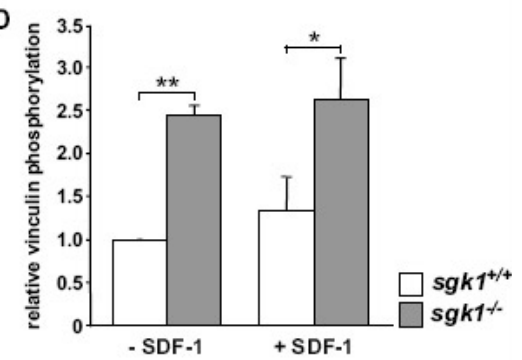

E

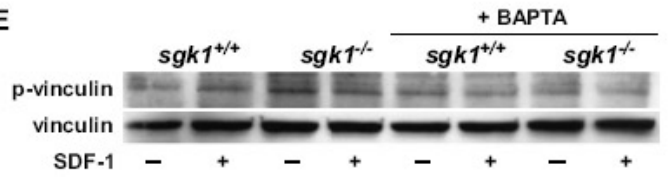

Fig. 3. Effect of SGK1 on vinculin phosphorylation in SDF-1-stimulated murine platelets. A. Immunofluorescence stainings of vinculin phosphorylation in platelets isolated from $s g k 1^{+/+}$(left panels) or $s g k 1^{\%-}$ (right panel) mice without (top) or with (bottom) exposure to SDF-1 (100 ng/ml) for 30 minutes. Red - actin, green phosphorylated vinculin. Scale bar equals $5 \mu \mathrm{m}$. B. Arithmetic means \pm SEM $(n=5)$ of the immunofluorescence intensity of vinculin phosphorylation in platelets isolated from $s g k 1^{+/+}$(white bars) or $s g k 1^{\%}$ mice (grey bars) without (left) or with (right) exposure to SDF-1 $(100 \mathrm{ng} / \mathrm{ml})$ normalized to $1{ }^{*}(\mathrm{p}<0.05)$ or ${ }^{* *}(\mathrm{p}<0.01)$ indicate statistically significant difference. C. Original western blot of the abundance of phosphorylated vinculin in platelets isolated from $s g k 1^{+/+}$or $s g k 1^{/-}$mice without (control) or with exposure to SDF-1 (100 $\mathrm{ng} / \mathrm{ml}$ ) for 30 minutes. Total vinculin protein abundance served as loading control. D. Arithmetic means \pm SEM ( $\mathrm{n}=3$ ) of the abundance of phosphorylated vinculin from western blot in platelets isolated from $s g k 1^{+/+}$ (white bars) and $s g k 1 \%$ (grey bars) mice without (left) or with (right) exposure to SDF-1 (100 ng/ml) for 30 minutes. ${ }^{*}(\mathrm{p}<0.05)$ or ${ }^{* *}(\mathrm{p}<0.01)$ indicate statistically significant difference. E. Original western blot of the abundance of phosphorylated vinculin in platelets isolated from $s g k 1^{+/+}$or $s g k 1^{\%-}$ mice without (control) or with prior exposure to SDF-1 (100 ng/ml) for 30 minutes in absence (left) or presence (right) of the $\mathrm{Ca}^{2+}$ chelator BAPTA (30 $\mu \mathrm{M}, 1$ hour).

\section{Discussion}

The present study reveals that migration of platelets is sensitive to the presence of the serum- and glucocorticoid-inducible kinase 1 (SGK1), a kinase downstream of phosphatidylinositide-3 kinase (PI3K). Earlier, we have shown that SDF-1 stimulates migration through a signaling cascade including CXCR4 receptor, pertussistoxin sensitive 


\section{Cellular Physiology $\quad$ Cell Physiol Biochem 2012;30:259-268

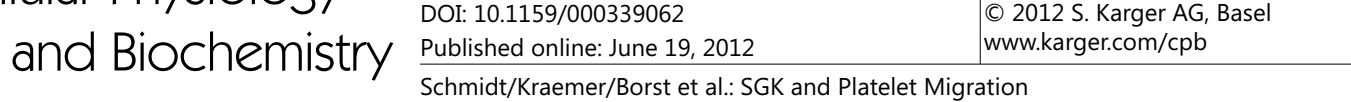

A

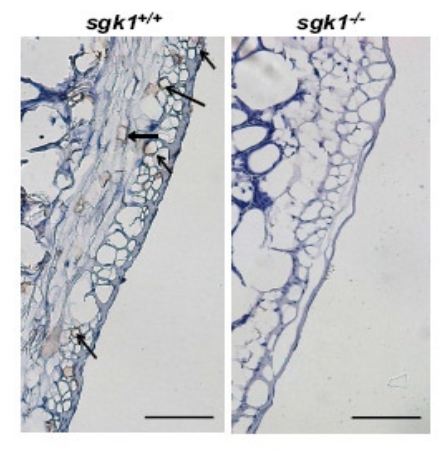

B

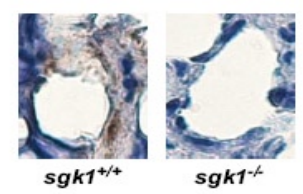

C

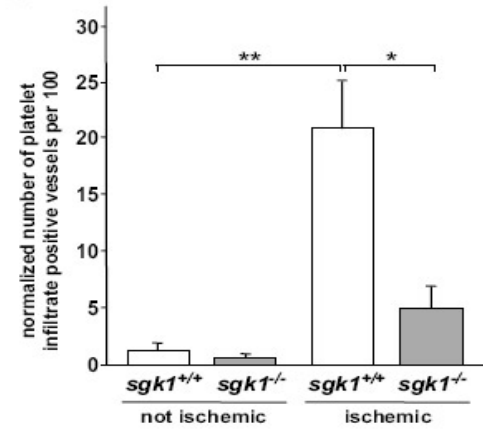

Fig. 4. Transmigration of $s g k 1^{+/+}$and $s g k 1^{-/}$platelets into ischemic vascular wall. A. Representative original photographs of transmigrated platelets (arrows) into the ischemic vascular walls of wild type littermates $\left(s g \mathrm{k1}^{+/+}\right)$and mice lacking SGK1 $\left(\mathrm{sgk1} 1^{-/}\right)$, stained for platelet-specific glycoprotein Ib $\alpha$. Scale bar equals 100 $\mu \mathrm{m}$. B. Enlarged original photographs demonstrating intramural platelet infiltrates in post-ischemic blood vessel of $s g k 1^{+/+}$mice (left) in comparison to $s g k 1^{\%}$ mice (right). C. Arithmetic means \pm SEM of the number of platelet infiltrate positive vascular walls (per 100 ischemic vessels) in $s g k 1^{-/}$mice and $s g k 1^{+/+}$mice after intestinal artery ligation compared to non-ischemic vessels. ${ }^{* *}(\mathrm{p}<0.01)$ or ${ }^{*}(\mathrm{p}<0.05)$ indicate statistically significant difference.

G-proteins and PI3K [3]. PI3K is involved in the signaling governing migration in other cell types [26]. PI3K leads to activation of SGK1 via phosphoinositide dependent kinase 1 (PDK1) [21], which has been shown to participate in the signaling of endothelial cell migration [27]. We could show that SGK1 critically influences platelet calcium signaling by regulation of the store operated calcium entry (SOCE) channel subunit Orai1 [24]. Furthermore, in recent studies we found that platelet migration requires activity of the calcium channel Orai1 and the calcium-dependent potassium channel SK4 $\left(\mathrm{K}_{\mathrm{Ca}} 3.1\right)$ [28].

According to our results migration is markedly decreased in $s g k 1$-deficient platelets compared to platelets isolated from wildtype littermates prior to and following stimulation of platelet migration by SDF-1 (Fig. 1). Thus, SGK1 plays a decisive functional role in platelet migration. SGK1 deficiency affected both, undirected, random migration and directed migration towards a chemoattractant. Cells may display mobility even in the absence of chemoattractants $[29,30]$. Undirected motility results from random extension of pseudopodia, which may be shaped by alterations of cytoskeletal structure [30]. Directional motility requires the sensing of spatial stimuli [30]. As SGK1 presumably affects the machinery underlying motility it modifies both, random and directed motility.

In the present study we have further determined phosphorylation of WASP and vinculin as they have been studied as established markers of cell mobility [3]. Our observations reveal that phosphorylation of Wiskott-Aldrich syndrome protein (WASP) is sensitive to SGK1 (Fig. 2). WASP phosphorylation following stimulation of platelet migration has been shown before $[3,6]$. Interestingly, WASP-phosphorylation was already reduced at baseline in sgk1deficient platelets. In other cell types [7-9] WASP has been shown to be critically involved in the process of cellular migration.

A further important regulator of cellular migratory activity is vinculin [10-12]. Vinculin stabilizes focal adhesions and thus, suppresses cell migration by regulating adhesion dynamics $[31,32]$. In a recent study we have already shown that platelets with single focal 


\section{Cellular Physiology Cell Physiol Biochem 2012;30:259-268 \\ \begin{tabular}{ll|l} 
and Biochemistry & $\begin{array}{l}\text { DOI: 10.1159/000339062 } \\
\text { Published online: June 19, } 2012\end{array}$ & $\begin{array}{l}\text { C 2012 S. Karger AG, Basel } \\
\text { www.karger.com/cpb }\end{array}$ \\
\cline { 2 - 3 } Schmidt/Kraemer/Borst et al.: SGK and Platelet Migration
\end{tabular}}

adhesion contacts show an enhanced migratory activity compared to platelets with classical multifocal adhesions [3]. The activation of vinculin via phosphorylation seems to be an important step controlling cell motility. In our experiments vinculin phosphorylation also appears to reflect the general migratory capacity of platelets and was affected by SGK1. It has been reported that vinculin phosphorylation mediates vinculin-dependent focal adhesion contacts [33] and controls cell motility in colon cancer cells [13] and HEK293 cells [34]. A decreased phosphorylation of vinculin results in enhanced migration of affected cells [33]. In human embryonic kidney cells SGK1 regulates vinculin phosphorylation and thereby upregulates the migratory potential [34]. In our study we could show that the abundance of phosphorylated vinculin is in platelets similarly regulated by SGK1 (Fig. 3). Vinculin phosphorylation was increased in $s g k 1 \%$ platelets, which is expected to decrease migratory capacity. Whereas SDF-1 had no effect on platelet vinculin phosphorylation (Fig. 3), the degradation of vinculin was found to be sensitive to cytosolic $\mathrm{Ca}^{2+}$ activity since the increased vinculin phosphorylation in sgk1-deficient platelets was abolished in the presence of the $\mathrm{Ca}^{2+}$ chelator BAPTA. The partial $\mathrm{Ca}^{2+}$-dependency of cytoskeletal modifications in platelet migration is consistent with findings in other migrating cells [35]. Platelet migration seems to be particularly sensitive to $\mathrm{Ca}^{2+}$ entry via the SOCE channel Orai1 [28], which is in turn regulated by SGK1 [24].

Although we did not address actin restructuring in the present study, in view of our observations on SGK1-induced WASP and vinculin phosphorylation, the possibility of SGK1 sensitive actin rearrangement participating in the regulation of platelet migration could be considered.

Platelets were previously shown to transmigrate through a confluent endothelial monolayer towards a source of SDF-1 [3]. Similar to SDF-1 fMLP (N-formylmethionyl-leucylphenylalanine) stimulates platelet migration in vitro [2] and extravasation into inflamed tissue in vivo [36]. Moreover, platelet migration and extravasation in lung tissue is triggered by IgE [4]. As SDF-1 is highly expressed in atherosclerotic plaques [14], the SDF-1 induced stimulation of platelet migration may contribute to the pathophysiology of atherosclerosis. There is growing evidence that platelets are involved in the pathogenesis of inflammatory diseases [37]. Especially vascular inflammation underlying early atherogenesis is presumably critically influenced by platelets interacting with the vascular wall [38]. After intestinal artery ligation and subsequent post-ischemic inflammatory reaction, platelets rapidly migrate into the vessel wall [3]. Accumulation of GFP-labeled platelets was more pronounced in areas of the post-ischemically inflamed vessel wall than in non-ischemic vessel areas [3]. Thus, platelets could serve as sentinel cells attracting further platelets or inflammatory cells like monocytes or stem cells $[37,39,40]$ into areas of vascular inflammation, which is followed by release of inflammatory cytokines such as IL-1 $\beta$ or SDF- 1 from platelets $[38,41]$. In the present study we found that sgk1-deficient platelets showed a markedly decreased transmigration into the vascular wall after ischemia in vivo (Fig. 4) which suggests an important role of SGK1 in the regulation of platelet migration in vivo.

In conclusion, SGK1 participates in the signaling of platelet migration. The kinase is at least partially effective by regulating platelet $\mathrm{Ca}^{2+}$ signaling (SOCE) resulting in a decreased abundance of phosphorylated vinculin. SGK1-sensitive platelet migration may be pathophysiologically relevant in ischemic and inflammatory tissue.

\section{Acknowledgements}

We thank Jadwiga Kwiatkowska and Yvonne Riexinger for providing outstanding technical assistance. This study was supported by the Deutsche Forschungsgemeinschaft (KFO274 and SFB-TR19) and the Fortüne programme (1934-0-0 to 0.B. and 1910-0-0 to B.F.K.). 


\begin{tabular}{|c|c|c|}
\hline $\mathrm{Col}$ & Cell Physiol Biochem 2012;30:259-268 & \\
\hline and Binchemistry & $\begin{array}{l}\text { DOI: 10.1159/000339062 } \\
\text { Published online: June 19, } 2012\end{array}$ & $\begin{array}{l}\text { (c) } 2012 \text { S. Karger AG, Basel } \\
\text { www.karger.com/cpb }\end{array}$ \\
\hline
\end{tabular}

\section{References}

1 Berger G, Hartwell DW, Wagner DD: P-Selectin and platelet clearance. Blood 1998;92:4446-4452.

2 Czapiga M, Gao JL, Kirk A, Lekstrom-Himes J: Human platelets exhibit chemotaxis using functional N-formyl peptide receptors. Exp Hematol 2005;33:73-84.

3 Kraemer BF, Borst O, Gehring EM, Schoenberger T, Urban B, Ninci E, Seizer P, Schmidt C, Bigalke B, Koch M, Martinovic I, Daub K, Merz T, Schwanitz L, Stellos K, Fiesel F, Schaller M, Lang F, Gawaz M, Lindemann S: PI3 kinase-dependent stimulation of platelet migration by stromal cell-derived factor 1 (SDF-1). J Mol Med 2010;88:1277-1288.

4 Pitchford SC, Momi S, Baglioni S, Casali L, Giannini S, Rossi R, Page CP, Gresele P: Allergen induces the migration of platelets to lung tissue in allergic asthma. Am J Respir Crit Care Med 2008;177:604-612.

5 Valone FH, Austen KF, Goetzl EJ: Modulation of the random migration of human platelets. J Clin Invest 1974; 54:1100-1106.

6 Kraemer BF, Schmidt C, Urban B, Bigalke B, Schwanitz L, Koch M, Seizer P, Schaller M, Gawaz M, Lindemann S: High shear flow induces migration of adherent human platelets. Platelets 2011;22:415-421.

7 Blundell MP, Worth A, Bouma G, Thrasher AJ: The Wiskott-Aldrich syndrome: The actin cytoskeleton and immune cell function. Dis Markers 2010;29:157-175.

8 Takahashi K, Suzuki K: WAVE2, N-WASP, and Mena Facilitate Cell Invasion via Phosphatidylinositol 3Kinase-Dependent Local Accumulation of Actin Filaments. J Cell Biochem 2011;in press:

9 Thrasher AJ, Burns SO: WASP: a key immunological multitasker. Nat Rev Immunol 2010;10:182-192.

10 Kallergi G, Tsapara A, Kampa M, Papakonstanti EA, Krasagakis K, Castanas E, Stournaras C: Distinct signaling pathways regulate differential opioid effects on actin cytoskeleton in malignant MCF7 and nonmalignant MCF12A human breast epithelial cells. Exp Cell Res 2003;288:94-109.

11 Le Clainche C, Carlier MF: Regulation of actin assembly associated with protrusion and adhesion in cell migration. Physiol Rev 2008;88:489-513.

12 Ziegler WH, Liddington RC, Critchley DR: The structure and regulation of vinculin. Trends Cell Biol 2006;16:453-460.

13 Gu S, Papadopoulou N, Nasir O, Foller M, Alevizopoulos K, Lang F, Stournaras C: Activation of membrane androgen receptors in colon cancer inhibits the prosurvival signals Akt/bad in vitro and in vivo and blocks migration via vinvulin/actin signaling. Mol Med 2010;14:48-58.

14 Abi-Younes S, Sauty A, Mach F, Sukhova GK, Libby P, Luster AD: The stromal cell-derived factor-1 chemokine is a potent platelet agonist highly expressed in atherosclerotic plaques. Circ Res 2000;86:131-138.

15 Bleul CC, Fuhlbrigge RC, Casasnovas JM, Aiuti A, Springer TA: A highly efficacious lymphocyte chemoattractant, stromal cell-derived factor 1 (SDF-1). J Exp Med 1996;184:1101-1109.

16 Hamada T, Mohle R, Hesselgesser J, Hoxie J, Nachman RL, Moore MA, Rafii S: Transendothelial migration of megakaryocytes in response to stromal cell-derived factor 1 (SDF-1) enhances platelet formation. J Exp Med 1998;188:539-548.

17 Phillips R, Ager A: Activation of pertussis toxin-sensitive CXCL12 (SDF-1) receptors mediates transendothelial migration of $\mathrm{T}$ lymphocytes across lymph node high endothelial cells. Eur J Immunol 2002;32:837-847.

18 Zheng H, Fu G, Dai T, Huang H: Migration of endothelial progenitor cells mediated by stromal cellderived factor-1alpha/CXCR4 via PI3K/Akt/eNOS signal transduction pathway. J Cardiovasc Pharmacol 2007;50:274-280.

19 Ziegler M, Elvers M, Baumer Y, Leder C, Ochmann C, Schonberger T, Jurgens T, Geisler T, Schlosshauer B, Lunov O, Engelhardt S, Simmet T, Gawaz M: The Bispecific SDF1-GPVI Fusion Protein Preserves Myocardial Function After Transient Ischemia in Mice. Circulation 2012;125:685-696.

20 Clemetson KJ, Clemetson JM, Proudfoot AE, Power CA, Baggiolini M, Wells TN: Functional expression of CCR1, CCR3, CCR4, and CXCR4 chemokine receptors on human platelets. Blood 2000;96:4046-4054.

21 Lang F, Bohmer C, Palmada M, Seebohm G, Strutz-Seebohm N, Vallon V: (Patho)physiological significance of the serum- and glucocorticoid-inducible kinase isoforms. Physiol Rev 2006;86:1151-1178.

22 Lang F, Strutz-Seebohm N, Seebohm G, Lang UE: Significance of SGK1 in the regulation of neuronal function. J Physiol 2010;588:3349-3354.

23 Shumilina E, Zemtsova IM, Heise N, Schmid E, Eichenmuller M, Tyan L, Rexhepaj R, Lang F: Phosphoinositide-dependent kinase PDK1 in the regulation of Ca2+ entry into mast cells. Cell Physiol Biochem 2010;26:699-706. 


\section{Cellular Physiolosy Cell Physiol Biochem 2012;30:259-268 \begin{tabular}{ll|l} 
and BiOChemistry & $\begin{array}{l}\text { DOI: 10.1159/000339062 } \\
\text { Published online: June 19, } 2012\end{array}$ & $\begin{array}{l}\text { (c) 2012 S. Karger AG, Basel } \\
\text { www.karger.com/cpb }\end{array}$ \\
\cline { 2 - 3 } Schmidt/Kraemer/Borst et al.: SGK and Platelet Migration
\end{tabular}}

24 Borst O, Schmidt EM, Munzer P, Schonberger T, Towhid ST, Elvers M, Leibrock C, Schmid E, Eylenstein A, Kuhl D, May AE, Gawaz M, Lang F: The serum- and glucocorticoid-inducible kinase 1 (SGK1) influences platelet calcium signaling and function by regulation of Orai1 expression in megakaryocytes. Blood 2012;119:251-261.

25 Wulff P, Vallon V, Huang DY, Volkl H, Yu F, Richter K, Jansen M, Schlunz M, Klingel K, Loffing J, Kauselmann G, Bosl MR, Lang F, Kuhl D: Impaired renal $\mathrm{Na}(+)$ retention in the sgk1-knockout mouse. J Clin Invest 2002;110:1263-1268.

26 Choudhury GG, Karamitsos C, Hernandez J, Gentilini A, Bardgette J, Abboud HE: PI-3-kinase and MAPK regulate mesangial cell proliferation and migration in response to PDGF. Am J Physiol 1997;273:F931F938.

27 Primo L, di Blasio L, Roca C, Droetto S, Piva R, Schaffhausen B, Bussolino F: Essential role of PDK1 in regulating endothelial cell migration. J Cell Biol 2007;176:1035-1047.

28 Schmidt EM, Munzer P, Borst O, Kraemer BF, Schmid E, Urban B, Lindemann S, Ruth P, Gawaz M, Lang F: Ion channels in the regulation of platelet migration. Biochem Biophys Res Commun 2011;415:54-60.

29 Petrie RJ, Doyle AD, Yamada KM: Random versus directionally persistent cell migration. Nat Rev Mol Cell Biol 2009;10:538-549.

30 Swaney KF, Huang CH, Devreotes PN: Eukaryotic chemotaxis: a network of signaling pathways controls motility, directional sensing, and polarity. Annu Rev Biophys 2010;39:265-289.

31 Bailly M: Connecting cell adhesion to the actin polymerization machinery: vinculin as the missing link? Trends Cell Biol 2003;13:163-165.

32 Critchley DR: Cytoskeletal proteins talin and vinculin in integrin-mediated adhesion. Biochem Soc Trans 2004;32:831-836.

33 Kupper K, Lang N, Mohl C, Kirchgessner.N., Born S, Goldmann WH, Merkel R, Hoffmann B: Tyrosine phosphorylation of vinvulin at position 1065 modifies focal adhesion dynamics and cell tractions. Biochem Biophys Res Commun 2010;399:560-564.

34 Schmidt EM, Gu S, Anagnostopoulou V, Alevizopoulos K, Foller M, Lang F, Stournaras C: Serum- and glucocorticoid-dependent kinase-1-induced cell migration is dependent on vinculin and regulated by the membrane androgen receptor. FEBS J 2012;279:1231-1242.

35 Miyazaki T, Honda K, Ohata H: Requirement of Ca2+ influx- and phosphatidylinositol 3-kinase-mediated m-calpain activity for shear stress-induced endothelial cell polarity. Am J Physiol Cell Physiol 2007;293: C1216-C1225.

36 Feng D, Nagy JA, Pyne K, Dvorak HF, Dvorak AM: Platelets exit venules by a transcellular pathway at sites of F-met peptide-induced acute inflammation in guinea pigs. Int Arch Allergy Immunol 1998;116:188-195.

37 von Hundelshausen P, Weber C: Platelets as immune cells: bridging inflammation and cardiovascular disease. Circ Res 2007;100:27-40.

38 Gawaz M, Langer H, May AE: Platelets in inflammation and atherogenesis. J Clin Invest 2005;115:33783384.

39 Stellos K, Langer H, Daub K, Schoenberger T, Gauss A, Geisler T, Bigalke B, Mueller I, Schumm M, Schaefer I, Seizer P, Kraemer BF, Siegel-Axel D, May AE, Lindemann S, Gawaz M: Platelet-derived stromal cell-derived factor-1 regulates adhesion and promotes differentiation of human CD34+ cells to endothelial progenitor cells. Circulation 2008;117:206-215.

40 von Hundelshausen P, Weber KS, Huo Y, Proudfoot AE, Nelson PJ, Ley K, Weber C: RANTES deposition by platelets triggers monocyte arrest on inflamed and atherosclerotic endothelium. Circulation 2001;103:1772-1777.

41 Lindemann S, Tolley ND, Dixon DA, McIntyre TM, Prescott SM, Zimmerman GA, Weyrich AS: Activated platelets mediate inflammatory signaling by regulated interleukin 1beta synthesis. J Cell Biol 2001;154:485-490. 